\title{
Did Cavemen Boil Their Food? A Remote Sensing Based Evidence of Hydrothermal Landscape of Prehistoric Mongoloid Pawon Man 9.5 ka Occupancy at Pawon Cave of West Java
}

Andri Wibowo*

\begin{abstract}
Keywords:
Cave, hydrothermal,

Landsat, Pawon,

remote sensing

*U. o. Indonesia, West Java, 16424. Indonesia.

Correspondence email:

paleobio2020@gmail.com

andri. wibowo
\end{abstract}

\begin{abstract}
Relationship between caveman prehistoric life in terms of heat induced food processing and its geological ecosystems have received many attentions. Previous studies have investigated the sources of heat included using Fourier transform infrared spectroscopy and biomarker approaches. Here this study proposes the use of remote sensing to identify the relationship of 9500 year old (9.5 ka) prehistoric mongoloid occupancy with hydrothermal manifestations at Pawon cave of West Java. The hydrothermal manifestations around Pawon cave were identified using Landsat 8 band combinations, land surface temperature, and sedimentary lithology. The results showed the hydrothermal manifestations surrounding Pawon cave were within a distance of $0.5-2 \mathrm{~km}$. The results also showed bones representing 12 animal taxon groups with high abundance of rodents. To conclude this study sheds the light of proximity and preferences of mongoloid prehistoric occupancy towards hydrothermal landscape due to its advantage as heat sources for food processing purposes.
\end{abstract}

\section{Introduction}

How our ancient ancestors live is very interesting study areas. Recently, there were growing studies regarding the activities of the caveman including how they process their foods. A comprehensive study about how the caveman using heat sources to process their food can be seen by study by Henry (2017). The most common heat sources were coming by burning some materials. The uses of heat sources in food processing among hominins have been recorded as late as the Middle Paleolithic. During that time, Neanderthals have started maintained fires though were not able to manufacture them (Sandgathe et al. 2011).

Most of the caveman studies on how they were using heat sources were conducted outside Asia. In Africa, from 1.0 to 1.6 million year ago (Ma), there were evidences ranging from burned lithics in Koobi Fora, Kenya (Clark \& Harris 1985) to burned bones in Wonderwerk, South Africa (Berna et al. 2012). In Europe, the evidences included charcoal, burned hearth, and bones excavated from England, France, Germany Hungary, Italy, and Spain (Roebroeks \& Villa 2011, Preece et al. 2006). In Asia, the caveman cooking studies were limited to southwest parts of Asia with evidences of charcoal, burned seeds, and bones (Albert et al. 1999, Alperson-Afil \& Goren-Inbar 2010, Shahack-Gross et al. 2014, Shahack-Gross et al. 1997). Most of those studies were only presenting the sources of heat were from burning some materials. Likewise, none of those studies were discussing about the use of boiled water to process food.

Java island is one of the locations where hominins were found ranging from Pithecanthropus (Simanjuntak 2001, Widianto 2006), Homo erectus (Alink et al. 2016) to Pawon man (Nurani \& Murti 
2017) and Wajak man (Setiyabudhi et al. 2019). The evidences of hominins can be found mostly in caves widely distributed along Java landscape. On the period of 2003-2004, an estimated 9500 year old mongoloid skeleton was found inside the Pawon cave in west Java (Yondri 2010). Regarding this, the study aims to seek the evidences of hominins in cooking food. Since cooking food requiring heat sources, this study also seeks the use of hydrothermal as the source of heats.

\section{Methods}

The study area was in the Pawon cave located in the Gunungmasigit highland of west Java at elevation of $716 \mathrm{~m}$ above sea level (Figure 1). The entrance of the cave was on the side of a cliff on south west direction. The length and width of this case were $38 \mathrm{~m}$ and $16 \mathrm{~m}$. The landscapes surrounded the cave were dominated by the forest covers. Inside the cave, the fossils were collected. Those fossils included the hominin bones, vertebrata bones, and mollusks (shells). Taxonomic identifications of excavated fossils were based on diagnostic features including molar size and morphology (Sody 1941, Hooijer 1957, Musser et al. 1986, Kitchener et al. 1991).
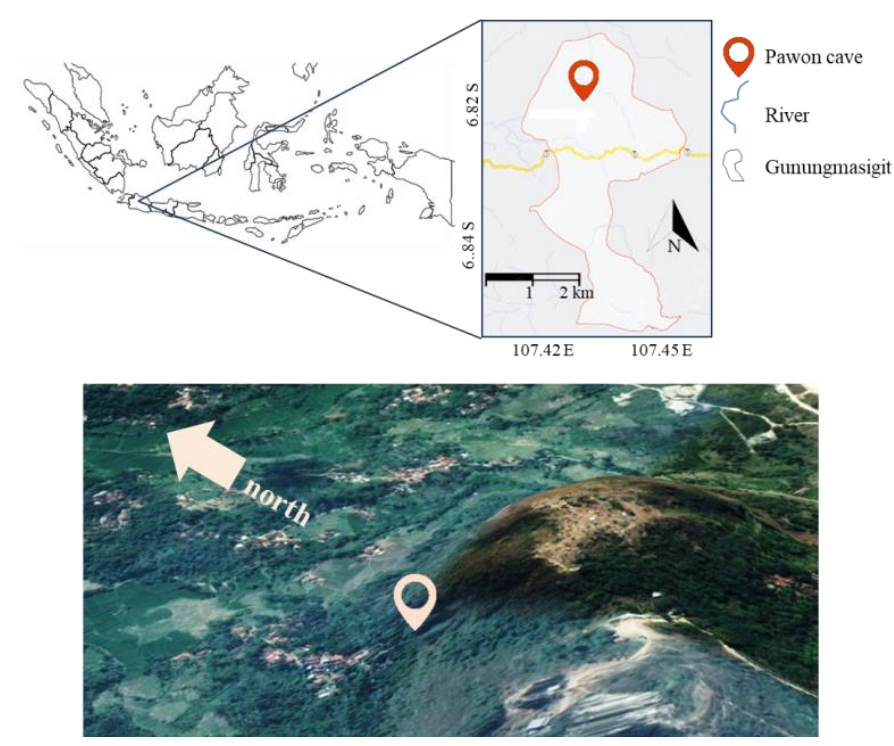

Figure 1. Location and landscape of Pawon cave located in Gunungmasigit highland of west Java.

The hydrothermal landscapes in Gunungmasigit highland were assessed using several geophysical properties including land surface temperature, lithology assemblage, and hydrothermal alterations. The measurements of land surface temperature (LST) and hydrothermal alterations were based on the remote sensing approach. LST was measured following methods by Putra et al. (2018) and Supriatna et al. (2019) and using processed Landsat 8 imagery data with the results shown are anomalous temperature changes that occurred in the hydrothermal manifestations in particular area. The formula for processing LST was: 


$$
\mathrm{T}=\frac{\mathrm{K} 2}{\ln \frac{\mathrm{K} 1}{\mathrm{CVr}}}
$$

Where $=$ temperature (celcius), $C V r=$ radiance value in the thermal band, $\mathrm{K}_{1}$ and $\mathrm{K}_{2}=$ constant in metadata of Landsat 8 imagery.

While identifications of hydrothermal alterations were using Landsat 8 imagery data with 2 wavelength combinations with ranged of $0.84-0.88 \mu \mathrm{m}, 1.57-1.65 \mu \mathrm{m}$, and 2.11-2.29 $\mu \mathrm{m}$ and $0.84-0.88$ $\mu \mathrm{m}, 2.11-2.29 \mu \mathrm{m}$, and $0.53-0.59 \mu \mathrm{m}$ for the second combination. This Landsat 8 remote sensing based hydrothermal alteration identification method was following Abubakar et al. (2017).

\section{Results}

There were 12 animal taxon groups represented in Pawon cave based on dental fossil records. The numbers of individuals of each taxon were varied. The orders of numbers of individuals for each taxon were Colobinae $>$ Cercopithecinae $>$ Rodentia $>$ Chiroptera $>$ Suidae $>$ Cervidae $>$ Cypriniformes $>$ Hylobatidae $>$ Bovidae $>$ Reptilia $>$ Carcahiniformes $>$ Traguliade.

The sedimentary lithology around Pawon cave in Gunungmasigit highland landscape can be seen in Figure 2. There were 2 prominent features of rock types near the cave. The northern parts of Gunungmasigit near the cave were dominated by Pleistocene limestone. While the rock types in the distance of $2 \mathrm{~km}$ from the cave were dominated by alluvium rock types. The measurement on LST was showing trends related to the presumably occurrence of hydrothermal. The LST was ranging from $34{ }^{0} \mathrm{C}$ to $35{ }^{\circ} \mathrm{C}$. While most Gunungmasigit landscapes especially in the southern parts were having higher LST equals to $35^{\circ} \mathrm{C}$. The LST in surrounding areas of the landscapes mainly in northern parts were lower than the southern parts with value equals to $34{ }^{0} \mathrm{C}$.

The hydrothermal alterations around the Pawon cave were presented in Figure 3. The alterations were measured using Landsat 8 with 2 different band combinations. First combination was including wavelength ranges of $0.84-0.88 \mu \mathrm{m}, 1.57-1.65 \mu \mathrm{m}, 2.11-2.29 \mu \mathrm{m}$ and the second combination was using wavelength ranges of $0.84-0.88 \mu \mathrm{m}, 2.11-2.29 \mu \mathrm{m}, 0.53-0.59 \mu \mathrm{m}$ of the Landsat 8 data. Both combinations have shown the geological features and characteristics ranged from the textured igneous and sedimentary rocks, structural features, and vegetation covers, which were are detected at regional scale. In Figure 3 vegetation covers around the cave appear in orange and light red for Landsat 8 first combination and dark red for second combination. While the light yellow and light green areas indicated the hydrothermal manifestations. Those hydrothermal areas were identified in the south of Pawon cave in a distance of $0.5-2 \mathrm{~km}$. 

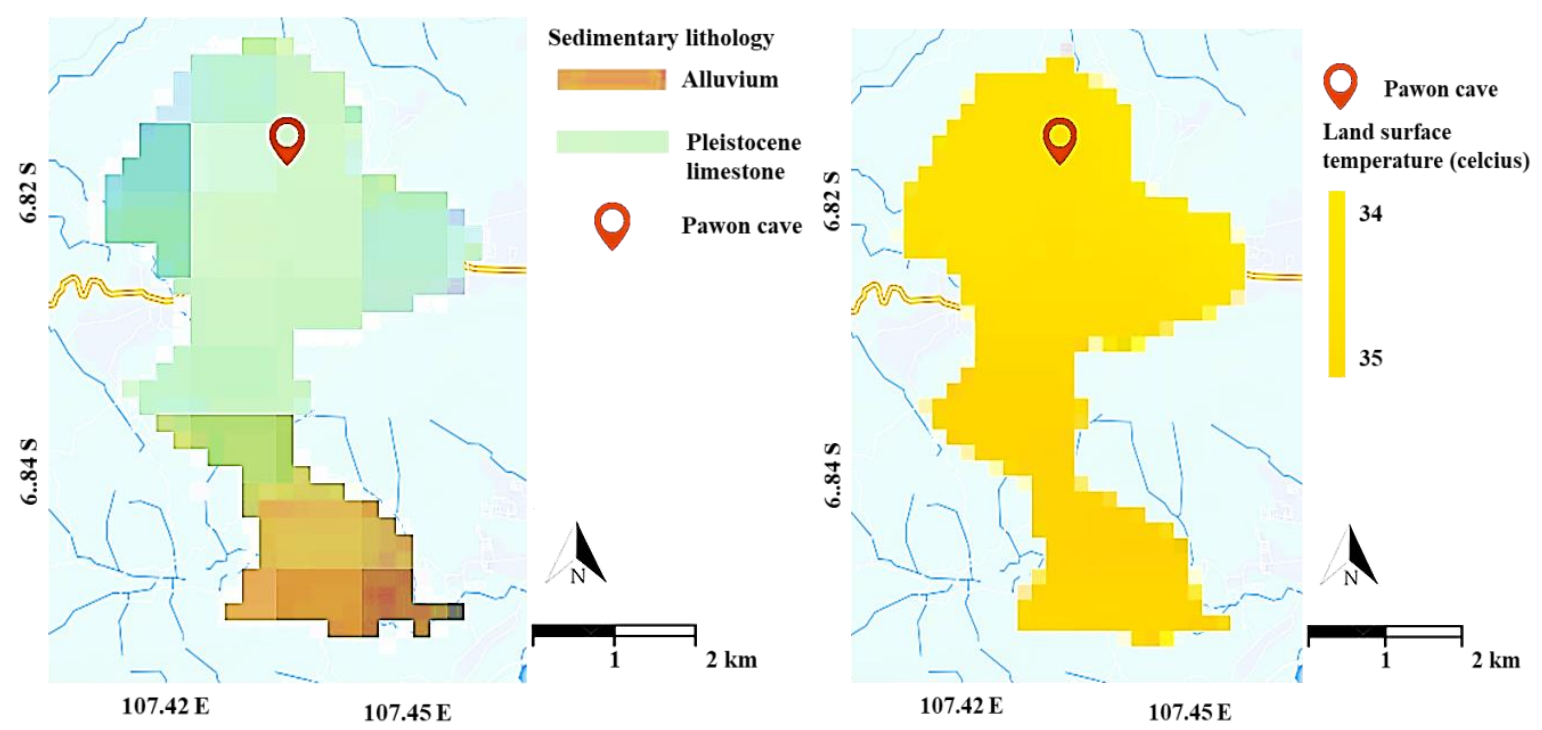

Figure 2. Sedimentary lithology (left) and land surface temperature $\left({ }^{0} \mathrm{C}\right)$ (right) of Gunungmasigit highland of west Java.
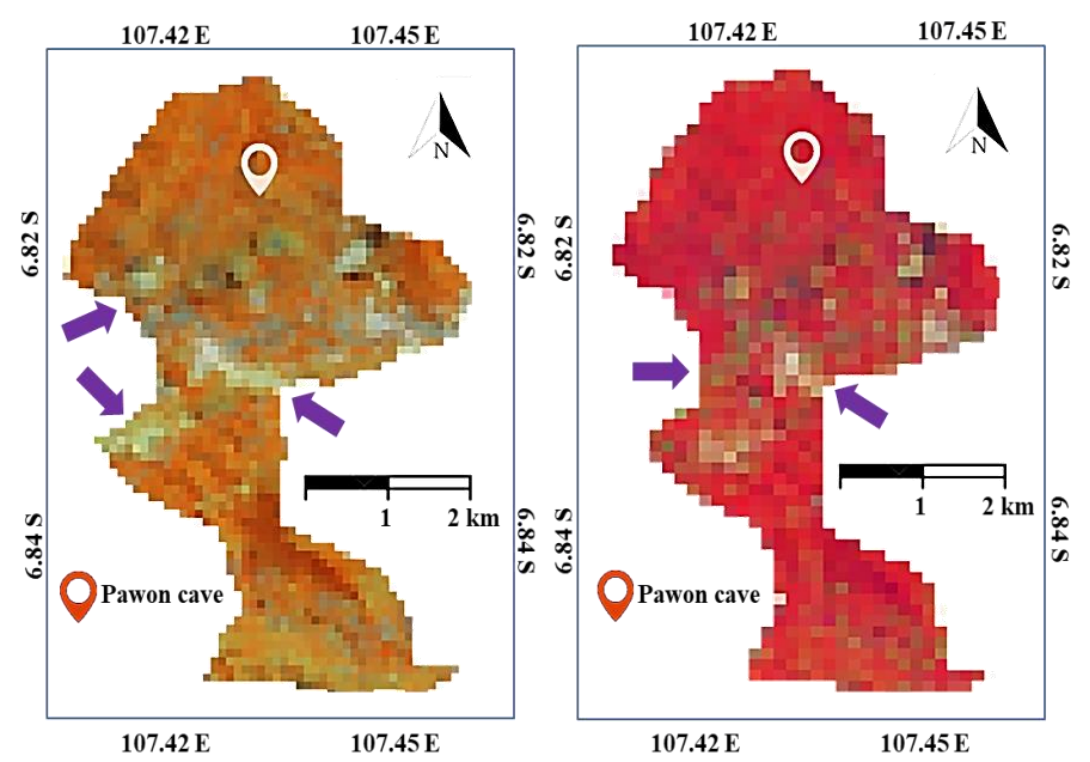

Figure 3. Hydrothermal alterations (arrow signs) of Gunungmasigit highland of west Java with Landsat 8 wavelength ranges of $0.84-0.88 \mu \mathrm{m}, 1.57-1.65 \mu \mathrm{m}, 2.11-2.29 \mu \mathrm{m}$ (left) and wavelength ranges of $0.84-0.88 \mu \mathrm{m}, 2.11-2.29 \mu \mathrm{m}, 0.53-0.59 \mu \mathrm{m}$ (right). 


\section{Discussion}

The presence of hydrothermal in a landscape can be identified by observing hydrothermal alterations. Hydrothermal sources are releasing water with high temperature ranging from $100{ }^{0} \mathrm{c}$ to $500{ }^{0} \mathrm{c}$. This hot water originally from magma fluid is flowing in the lithosphere and changing the chemical composition of rocks. On the surface, the hydrothermal water was visible as hot springs. The alteration of the rock caused by hot water then known as hydrothermal alterations and can be used to identify the occurrence of hydrothermal manifestations (Wohletz \& Heiken 1992, Torres-Ceron et al. 2019).

Numerous methods have been developed to identify hydrothermal manifestation mainly at landscape level and this includes the use of remote sensing. Hyper spectral sensors of remote sensing have ability to identify surface mineralogical composition (Huntington 1996). In this study, combinations of Landsat 8 band wavelengths have been used to identify hydrothermal manifestation. Landsat 8 is known as a versatile tool that has been used by many studies. In South Africa, Mahboob et al. (2019) have used Landsat 8 to map altered rocks in the Gauteng and Mpumalanga using combination of visible, near infrared, short wavelength infrared, and thermal infrared regions bands. In Iceland, (Ramírez-González et al. 2019) high temperature geothermal areas have been identified using combinations of visible and short wavelength infrared. Hydrothermal alteration zones hence can be interpreted based on thermal emission and reflection remote sensing data (Zamyad et al. 2019).

Java island (Purnomo \& Thomas 2014) is one of the landscape that has extensive hydrothermal manifestations from western parts (Setiawan et al. 2018), central, to eastern parts (Sumartato et al. 2020). While west Java has the largest hydrothermal manifestations accounted for $21.7 \%$ of national hydrothermal manifestation (Gaffar 2017). In west Java, the Pawon cave within Gunungmasigit landscape was the parts of Bandung basin. This basin and its surrounding area comprise volcanic rocks which are the geological resources of hydrothermal generated from past volcanic activities (Bronto \& Hartono 2006). This long geological history of Bandung basin and west Java is comparable to the hydrothermal manifestation around Pawon cave within Gunungmasigit landscape as identified in this study.

Besides extensive geological features in the term hydrothermal manifestations, Java island is also known for its prehistoric life and occupancies. Numerous proofs of prehistoric occupancies have been studied from the cave ecosystems (Nurani 2016) including Pawon cave. The occupants of this cave are estimated have done some activities include collecting and processing food, farming, and hunting on the modest level. Processing food activities supported by the presences of life tools made of bones, fragments of animal bones and teeth, and shells of mollusk (Azhari et al. 2017). Bone tools have been used to cut the mollusk meat (Nurfaridah et al. 2019). Animal tooth representing various taxon groups found indicated the food processing and consumption activities inside the cave during prehistoric life. This can be seen by 
high numbers of rodent bones reported in this study. Abundance of rodent bones in caves where carnivores were absent was related due to the consumption by either avian or hominin (Veatch et al. 2019). This is also supported by the dental attrition (Ahmad et al. 2017) of Pawon man indicating presumably consumption of hard foods sourced from animal teeth, bones, and mollusk. However study about how the hominins inhabited cave in Java have used heat sources or where they obtain the heat sources in food processing is still limited.

Relationship between caveman prehistoric in terms of heat induced food processing and its geological ecosystems have received many attentions. The food processing by caveman can be either by roasting or boiling, which booth requires heat sources (Bogin 1998). Comprehensive studies on the relations of prehistoric life to heat sources can be drawn from Hlubik et al. (2017). In Kenya the caveman-heat source relationships were identified using high resolution spatial analysis and Fourier transform infrared spectroscopy. However their study only emphasized on an evidence of burned materials which is the source of heat was fires. The Homo erectus caveman is hypothesized has burned some materials included bones and sediments to get the heat in the form of fire.

The studies on alternative sources of heat from surrounding ecosystems like hydrothermal have received many attentions as well. There are growing literatures of proximity of caveman occupancy to geothermal manifestations (Arriaga 2005). Several European and Asian civilizations where found near the hot springs. Vikings settlers were known using hot springs for washing clothes, boiling food, and bathing. A recent study (Sistiaga et al. 2020) in Olduvai gorge stream using molecular fossil biomarker from ancient plant and microbe has revealed 1.7 million year ago occupancy may has a proximity to hydrothermal manifestations. The biomarker analysis shows a typical hyperthermophilic microbes and this suggests that parts of the current streams may have surface temperatures as high as 80 to $90{ }^{\circ} \mathrm{C}$ with higher subsurface temperatures. These environmental conditions may allow early hominins to thermally process edible plants and meat by cooking. Since to cook the only requirement is heat and the heat sources were available from nearby hot springs.

In this study the closest identified hydrothermal manifestation from the cave was within a distance of $500 \mathrm{~m}$ in the south. This distance is within the hominin walking and foraging distance. Hominins especially Homo erectus and early Homo sapiens are more distinctive than mammals due to its bipedal locomotion and this gain the ability to walk and run long distances, and excels at long distance trekking (Lieberman et a. 2015). 


\section{Conclusions}

The occupancy of Pawon cave by prehistoric mongoloid was confirmed by animal bones. The location of cave was overlapped with a landscape that has vast hydrothermal manifestations. However, like the nature of paleontology, there is still a lot of materials out there has to be excavated to get the big picture of food processing using hydrothermal as heat source for boiling. To reach the solid conclusions that the Pawon man hominins presumably boiled their foods, a proof of boiling practices in the form of marks in the food remains indeed is still required.

\section{References}

Abubakar A, Hashim M. 2017. Identification of hydrothermal alteration minerals associated with geothermal system using ASTER and Hyperion satellite data: a case study from Yankari Park, NE Nigeria. Geocarto International. 1-57.

Ahmad A, Aripin D, Yondri L. 2017. Description of dental caries and effects of foods on tooth destruction in skulls of pawon man. Purbawidya: Jurnal Penelitian dan Pengembangan Arkeologi.

Albert RM, Lavi O, Estroff L, Zeiner S, Tsatskin A, Ronen A, Lev-Yadun S. 1999. Mode of occupation of Tabun Cave, Mt Carmel, Israel during the Mousterian Period: a study of the sediments and phytoliths. Journal of Archaeological Science 26(10):1249-1260.

Alink G, \& Roebroeks W, Simanjuntak T. 2016. The Homo erectus Site of Trinil: Past, Present and Future of a Historic Place. AMERTA.

Alperson-Afil N, Richter D, Goren-Inbar N. 2007. Phantom hearths and the use of fire at Gesher Benot Ya'aqov, Israel. PaleoAnthropology. 1-15.

Arriaga MCZ. 2005. A Short Story of the Long Relationship BetweenThe Human Race and Geothermal Phenomena. Proceedings World Geothermal Congress.

Azhari, Epsilawati L, Oscandar F, Wisam, Lutfi Y. 2017. The thickness and density of Pawon man mandible body cortical bone and alveolar using cone beam computed tomography (cbct). International Journal of Development Research. 7(11).

Berna F, Goldberg P, Horwitz LK, Brink J, Holt S, Bamford M, Chazan M. 2012. Microstratigraphic evidence of in situ fire in the Acheulean strata of Wonderwerk Cave, Northern Cape Province, South Africa. Proceedings of the National Academy of Sciences of the USA 109(20):E1215E1220.

Bogin B. 1998. From caveman cuisine to fast food the evolutionof human nutrition. Growth hormone $\&$ IGF research. 8: 79-86.

Bronto S \& Hartono U. 2006. Potensi Sumber Daya Geologi Di Daerah Cekungan Bandung Dan Sekitarnya. Indonesian Journal on Geoscience, 1(1).

Clark JD, Harris JWK. 1985. Fire and its role in early hominid lifeways. African Archaeological Review 
Gaffar EZ. 2017. The concept of geothermal exploration in west Java based on geophysical data. IOP Conf. Series: Earth and Environmental Science. 118.

Henry A. 2017. Neanderthal Cooking and the Costs of Fire. Current Anthropology. 58.

Hlubik S, Berna F, Feibel C, Braun D, Harris JWK. 2017. Researching the Nature of Fire at 1.5 Mya on the Site of FxJj20 AB, Koobi Fora, Kenya, Using High-Resolution Spatial Analysis and FTIR Spectrometry. Current Anthropology. 58(16).

Hooijer DA. 1957. Three new giant prehistoric rats from Flores Lesser Sunda Islands. Zoologische Mededelingen, 35: 299-314.

Huntington J. 1996. The Role of Remote Sensing in Finding Hydrothermal Mineral Deposits on Earth. Ciba Foundation symposium. 202. 214-31.

Kitchener DJ, How RA, Maharadatunkamsi. 1991. Paulamys sp. cf. P. naso (Musser, 191) (Rodentia: Muridae) from Flores Island, Nusa Tenggara, Indonesia — description from a modern specimen and a consideration of its phylogenetic affinities. Records of the Western Australia Museum. 15: 171-189.

LiebermanDE. 2015.Human Locomotion and Heat Loss: An Evolutionary Perspective. Comprehensive Physiology. 5.

Mahboob M, Genc B, Celik T, Ali S, Atif I. 2019. Mapping hydrothermal minerals using remotely sensed reflectance spectroscopy data from Landsat. Journal of the Southern African Institute of Mining and Metallurgy. 119.

Musser GG, van de Weerd A, Strausser E. 1986. Paulamys, a replacement name for Floresomys, Musser, 1981 (Muridae), and new material of that taxon from Flores, Indonesia American Museum Novitates, 2850: 1-10.

Nurfaridah D, Bawono RA, Kristiawan. 2019. Artefak Rijang Situs Gua Pawon. Humanis: Journal of Arts and humanities. 23(4).

Nurani IA. 2016. The cultural character of gua Kidang (Kidang cave), a prehistoric habitation site on the karst of the north mountains of Java. SBA.19(1).

Nurani IA, Murti DB. 2017. Three Homo Sapiens Skeleton Findings from Kidang Cave Identification and Paleoanthropology-Geoarchaeology Study. PURBAWIDYA: Jurnal Penelitian dan Pengembangan Arkeologi.

Preece RC, Gowlett JAJ, Parfitt SA, Bridgland DR, Lewis SG. 2006. Humans in the Hoxnian: habitat, context and fire use at Beeches Pit, West Stow, Suffolk, UK. Journal of Quaternary Science 21(5):485-496.3:3-27.

Purnomo B, Thomas P. 2014. Geothermal systems on the island of Java, Indonesia. Journal of Volcanology and Geothermal Research. 
Putra MIJ, Huda N, Afdhalia F, Supriatna. 2019. Onshore oil and gas reservoir detection through mapping of hydrocarbon microseepage using remote sensing IOP ConferenceSeries: Earth and Environmental Science.

Ramírez-González LM, Aufaristama M, JónsdóttirI, HöskuldssonA, pórðarson B, Proietti NM, Kraft G, McQuilkin J. 2019. Remote sensing of surface Hydrothermal Alteration, identification of Minerals and Thermal anomalies at Sveifluháls-Krýsuvík high-temperature Geothermal field, SW Iceland. IOP Conference Series: Earth and Environmental Science. 254.

Roebroeks W, Villa P. 2011. On the earliest evidence for habitual use of fire in Europe. Proceedings of the National Academy of Sciences of the USA 108(13):5209-5214.

Sandgathe DM. 2017. Identifying and describing pattern and process in the evolution of hominin use of fire. Current Anthropology 58: S360-S370.

Setiawan I, Sudarsono, Imtiyaz F, Yuliyanti A, Lintjewas L, Alkausar A, Jakah. 2018. Geothermal and volcanism in west Java. IOP Conference Series: Earth and Environmental Science. 118.

Setiyabudi E, Trihascaryo A, Koesbardiati T, Suriyanto RA, Murti DB. 2019. Geoconservation of Vertebrate and Human Ancient Fossils Site, The South TulungagungArea East Java 1. Jurnal Geologi dan Sumberdaya Mineral. 20(4).

Shahack-Gross R, Berna F, Karkanas P, Lemorini C, Gopher A, Barkai R. 2014. Evidence for the repeated use of a central hearth at Middle Pleistocene (300 ky ago) Qesem Cave, Israel. Journal of Archaeological Science 44(1):12-21.

Shahack-Gross R, Bar-Yosef O, Weiner S. 1997. Black-coloured bones in Hayonim Cave, Israel: differentiating between burning and oxide staining. Journal of Archaeological Science 24(5):439446.

Sistiaga A, Husain F, Uribelarrea D, Martín-Perea DM, Ferland T, Freeman KH, Diez-Martín F, Baquedano E, Mabulla A, Domínguez-Rodrigo M, Summons RE. 2020. Microbial biomarkers reveal a hydrothermally active landscape at Olduvai Gorge at the dawn of the Acheulean, 1.7 Ma. Proceedings of the National Academy of Sciences.

Simanjuntak T. 2001. New Insight on the Tools of the Pithecanthropus, inside Truman Simanjuntak, dkk. ed., Sangiran: Man, Culture, and Environment in Pleistocene Times, pp. 154-170. Jakarta: YOI.

Sody HJV. 1941. On a collection of rats from the Indo-Malayan and Indo-Australian regions. Treubia, 18: 255-325.

Sumotarto U, Hendrasto F, Meirawati M, Azza I. 2020. Geology of Arjosari geothermal area, Pacitan, East Java. AIP Conference Proceedings. 2245.

Supriatna S, Susiloningtyas D, Firdaus N 2018 Sustainability Landscape Spatial Model for Kemiri Sunan Crop at Pongkor Mining and Surrounding Area, Indonesia AIP Conference 
Proceedings.

Torres-Ceron DA, Acosta-Medina CD, Restrepo-Parra E. 2019. Geothermal and Mineralogic Analysis of Veatch EG, Tocheri MW, Sutikna T, McGrath K, Saptomo EW, Jatmiko, Helgen KM. 2019. Temporal shifts in the distribution of murine rodent body size classes at Liang Bua (Flores, Indonesia) reveal new insights into the paleoecology of Homo floresiensis and associated fauna. Journal of Human Evolution. 130: 45-60.

Widianto. 2006. Dari Pithecanthropus ke Homo erectus : Situs, Stratigrafi dan Pertanggalan Temuan Fosil Manusia di Indonesia. Berkala Arkeologi Tahun XXVI Edisi No. 2 /November. 114-129. Yogyakarta: Balai Arkeologi.

Wohletz K, Heiken G. 1992. Volcanology and Geothermal Energy.

Yondri L. 2010. Research Report of Penelitian Prasejarah Penggalian Arkeologi (Ekskavasi) di Gua Pawon Desa Gunung Masigit, Kecamatan Cipatat, Kabupaten Bandung Barat, Provinsi Jawa Barat.

Zamyad M, Afzal P, Pourkermani M. 2019.. Determination of Hydrothermal Alteration Zones Using Remote Sensing Methods in Tirka Area, Toroud, NE Iran. J Indian Soc Remote Sens 47: 18171830. 